\title{
The use of an abolished school building for a research facility in partnership between a municipality and university
}

\author{
Hiroki Ito ${ }^{1}$ \\ ${ }^{1}$ MPP student at the Blavatnik School of Government, University of Oxford
}

\begin{abstract}
.
As public facility management has been a challenge for municipalities under the population decrease and financial difficulties, the merge of schools has been increasing the number of abolished school buildings. In Koriyama City, Fukushima Prefecture, Japan, College of Engineering, Nihon University has been using an abolished school building for a research facility on shallow earth thermal for public houses based on a contract with Koriyama City Government in a close relationship with its regional plans. By analysing this case, this study aims to clarify (1) the process of the case, (2) the significance and challenges for municipalities, university, and region, and (3) the contribution to policy objectives such as the spread of renewable energy sources and industrial development. It concludes that (1) favourable relationships between the municipality and the university enabled the use of the school building, (2) the project and partnership are significant to find a means to bring the results of research to society and a way to use the abandoned school, (3) administrative burdens should be eased and (4) the use of the abandoned school buildings can work to push the policies of renewable energy adoption and industry building. It proposes that municipalities should (1) create regulations such as guidelines for sharing costs and procedures for simplifying processes, (2) assess the current state of each abandoned school building and present it, (3) set a framework for subsidies and (4) take on a support role to put research results back into the community.
\end{abstract}

Keywords: contract between a municipality and a university, industrial development, public facility management, renewable energy, shallow earth thermal

\section{Introduction}

With a declining population and deepening fiscal issues in local governments, management of public facilities is an important administrative issue. There has been a string of mergers between municipalities, and many elementary schools, in particular, have either closed or consolidated. Policies must be explored as to how best to leverage abandoned school buildings. 


\section{2nd International Conference on Applied Research in BUSINESS, MANAGEMENT and ECONOMICS}

\section{5-27 September 2020 Berlin, Germany}

At the same time, partnerships between municipalities and universities have been rapidly increasing since $2003^{1}$ (Cabinet Secretariat Urban Rebuilding Headquarters; 2005/2007). Through these partnerships, measures have unfolded in various fields based on the research of universities and the participation of students.

It is against this backdrop that we shall consider how partnerships between municipalities and universities can function as methods for leveraging abandoned school buildings. For example, the city of Koriyama in Fukushima Prefecture entered into an agreement with Nihon University's College of Engineering, located within its boundaries, to use abandoned school buildings as a research facility for renewable energy, including the development of technology aiming to make an ongoing business of a "shallow geothermal heat utilisation system for general housing" (hereinafter referred to as the "initiative"). The purposes of this initiative are the "development of renewable energy technologies," "creation of regional industries using the results of research," and "creating a highly distinctive region". There have been concerns about the energy supply after the accident with Tokyo Electric's Fukushima number one nuclear reactor, and the city of Koriyama is striving for the adoption of renewable energy. Thus this initiative is in line with the city's goals.

Little research has been done on "cases using abandoned school buildings as facilities for municipalities and universities to partner in conducting research that contributes to policy goals". This case study is unlike those that restructure or eliminate public facilities in the name of efficiency in that, being highly relevant to the municipalities' own regional plans, proactive use of public facilities that were once abandoned is a way to contribute to the achievement of policy goals laid out in municipality plans. Also, identifying its significance and issues gives suggestive conclusions in promoting the management of public facilities and the regional plans. Therefore, the goal of this study is to use the case of the city of Koriyama and Nihon University's College of Engineering to identify "processes," "the significance of, and issues with the various parties," and the "contribution to the dissemination of renewable energy and regional revitalisation through industrial promotion".

\section{Details of the Initiative, and Policy Positioning and Objectives}

\subsection{Details of the Initiative and its Objectives}

The city of Koriyama and the Nihon University College of Engineering entered into an "Agreement Regarding Research and Development of Renewable Energy" (hereinafter referred to as the "agreement") in November 2014. Based on this agreement, the "Koriyama and Nihon University College of Engineering Renewable Energy Joint Research Center" (hereinafter referred to as the "research facilities") was opened in September 2015. The Nihon University College of Engineering's Mechanical Engineering Department Renewable Energy Systems

${ }^{1} 20$ partnerships between local governments and universities were entered into in 2001; 34 in 2002; 89 in 2003; 136 in 2004; 202 in 2005; and 203 in 2006.

${ }^{2}$ A system for supplying heat for general housing heating and cooling using geothermal heat coming from relatively shallow areas 5 to 20 me-ters below the surface. 


\section{2nd International Conference on Applied Research in BUSINESS, MANAGEMENT and ECONOMICS}

\section{5-27 September 2020 Berlin, Germany}

Lab aims to make "shallow geothermal heat utilisation system for general housing" an ongoing business. More than forty private companies from within and without the prefecture are involved, making this a true industry-government-academia project.

Mass media information from the city of Koriyama on the project ${ }^{3}$ (November 11, 2014) states that the purpose of the initiative is to "contribute to greater development of renewable energy technologies and the building of regional industry leveraging research, as well as the creation of a more distinctive region".

\subsection{Energy Policies, Urban Planning, and Initiative Positioning}

\subsubsection{Energy Policies}

A goal of the "Koriyama Energy Vision" (Koriyama City Living Environment Section; 2015 ) is to reduce energy consumption by $20 \%$ by 2020 compared to 2011 , with $30 \%$ of the energy consumption coming from renewable energy. To do this, the plan lists seven critical projects such as "implementing new energy".

Table 1: Descriptions in "Koriyama City Energy Vision"

\begin{tabular}{|c|c|c|}
\hline Chapter \& Chapter & Related Terms \& Frequency & Analysis of Text \\
\hline $\begin{array}{l}\text { Chapter 1: Vision Background and } \\
\text { Positioning } \\
\text { 1-4 New Energy Trends }\end{array}$ & $\begin{array}{l}\text { Agreement } 1 \\
\text { Akatsu Elem. } 1 \\
\text { Nihon University College of } \\
\text { Engineering } 3 \\
\text { Shallow geothermal } 3\end{array}$ & $\begin{array}{l}\text { Reference to "initiative in } \\
\text { Koriyama" using geothermal heat } \\
\text { "Expected dissemination and } \\
\text { expansion" through improvements } \\
\text { "Supporting } \\
\text { industry-government-academia } \\
\text { project." }\end{array}$ \\
\hline $\begin{array}{l}\text { Chapter } 3 \text { : Koriyama city demand for } \\
\text { energy } \\
\text { 3-2 Implementations of renewable } \\
\text { energy and its issues }\end{array}$ & $\begin{array}{l}\text { Nihon University College of } \\
\text { Engineering } 3 \\
\text { Shallow geothermal } 1\end{array}$ & $\begin{array}{l}\text { While there has been "no progress" } \\
\text { on "use of unused heat," "shallow } \\
\text { geothermal heat" is referenced }\end{array}$ \\
\hline $\begin{array}{l}\text { Chapter 4: Current Renewable } \\
\text { Energy in Koriyama and Its Potential } \\
4-2 \text { A Summary of Potential } \\
\text { Renewable Energy Implementations } \\
\text { in Koriyama }\end{array}$ & $\begin{array}{l}\text { Nihon University College of } \\
\text { Engineering } 1 \\
\text { Shallow geothermal } 1\end{array}$ & $\begin{array}{l}\text { Reference to a case with technology } \\
\text { for "potentially implementing } \\
\text { geothermal energy." }\end{array}$ \\
\hline $\begin{array}{l}\text { Chapter 5: Basic Thinking When } \\
\text { Implementing New Energy } \\
\text { (Renewable Energy) } \\
5-2 \text { Goals When Implementing } \\
\text { Renewable Energy }\end{array}$ & $\begin{array}{l}\text { Nihon University College of } \\
\text { Engineering } 1 \\
\text { Shallow geothermal } 1\end{array}$ & $\begin{array}{l}\text { Statement of } 5 \% \text { energy reduction as } \\
\text { an example of "using shallow } \\
\text { geothermal energy" } \\
\text { "cutting-edge technology." }\end{array}$ \\
\hline $\begin{array}{l}\text { Chapter 6: Important Initiatives in } \\
\text { Implementing New Energy }\end{array}$ & $\begin{array}{l}\text { Akatsu Elem. } 1 \\
\text { Nihon University College of }\end{array}$ & $\begin{array}{l}\text { Explanation of this initiative as an } \\
\text { example of "initiatives for } \\
\text { industry-academia-finance-industrial }\end{array}$ \\
\hline
\end{tabular}

\footnotetext{
${ }^{3}$ Media materials related to the initiative have been published by the Industry and Tourism Department's Industry Creation Section, and on this point the initiative touches on industry building policies.
} 


\section{2nd International Conference on Applied Research in BUSINESS, MANAGEMENT and ECONOMICS}

\section{5-27 September 2020} Berlin, Germany

\begin{tabular}{|l|l|l|}
\hline 6-2 Initiatives in Important Projects & Engineering 1 & $\begin{array}{l}\text { research-academia partnerships" in } \\
\text { important projects }\end{array}$ \\
\hline List of Terms & Agreement 1 & $\begin{array}{l}\text { Explanation of "Agreement } \\
\text { Regarding Research and } \\
\text { Development of Renewable Energy } \\
\text { Technology" and "shallow } \\
\text { geothermal heat utilisation system." }\end{array}$ \\
& Akatsu Elem. 1 \\
& Nihon University College of \\
& Engineering 1 \\
& Shallow geothermal 2 & \\
\hline
\end{tabular}

Source: "Koriyama City Energy Vision”

Based on statements made in the "Koriyama Energy Vision," the city of Koriyama believes the current initiative to be one means of achieving its goals and can be read as providing support for developments in the initiative because of the anticipated results (Table 1). The documents give "regional revitalisation using energy-related industries" as an important project, and on this point as well there is consistency with the goals of the initiative. Based on the above, it can be said that the initiative has a certain standing given the energy policies of the city.

\subsubsection{Urban Planning}

The city of Koriyama created its first urban master plan 4 in 2000 , titled "City of Koriyama Urban Master Plan 2000". Since that time, the plan has been revised in 2010 and 2015 (Table 2). The most recent "Urban Master Plan 2015" (June 2015) summarises five points in the revised version (Koriyama City Urban Planning Section 2015). Regarding the environment, it notes "demonstrate policies for creating a low-carbon city through laws promoting low-carbon usage in urban areas". It would appear that the issue of reducing carbon use is of greater importance in the urban planning of Koriyama due to the earthquake.

Table 2: Urban Master Plan and Background and Important Points of Revisions

\begin{tabular}{|l|l|l|}
\hline & \multicolumn{1}{|c|}{ Background to Revision } & \multicolumn{1}{c|}{ Revision Details } \\
\hline $\begin{array}{l}\text { Koriyama Master } \\
\text { Version) (2010) }\end{array}$ & $\begin{array}{l}\text { Declining population and other major shifts } \\
\text { in societal structure accompanying rapid } \\
\text { declining birthrates and ageing population }\end{array}$ & $\begin{array}{l}\text { Change future urban structure to } \\
\text { "concentrated urban structure." }\end{array}$ \\
\hline $\begin{array}{l}\text { Koriyama Master } \\
\text { Urban Plan 2015 }\end{array}$ & $\begin{array}{l}\text { Changes to societal dynamics due to the } \\
\text { impact of the Great East Japan Earthquake } \\
\text { and Fukushima No. 1 Reactor Accident, } \\
\text { and revisions to various laws and system } \\
\text { regarding urban plans }\end{array}$ & $\begin{array}{l}\text { Five points, such as "demonstrate role } \\
\text { required of Koriyama in disaster } \\
\text { rebuilding," "demonstrate policies for } \\
\text { creating low-carbon city through laws } \\
\text { promoting low-carbon usage in urban } \\
\text { areas." }\end{array}$ \\
\hline
\end{tabular}

Source: Koriyama City Government Website

One can see descriptions of this initiative in policies for the "Konan Region" section of "Plans by Region" (Table 3), as this can be read as an intention to use the initiative to build up industry and the region. The initiative is given certain standing even in the Koriyama urban plan.

\footnotetext{
${ }^{4}$ A plan which each municipality creates to define concrete future goals and visions of urban planning and to propose challenges and basic direction to address them (Ministry of Land, Infrastructure, Transport and Tourism).
} 


\section{2nd International Conference on Applied Research in BUSINESS, MANAGEMENT and ECONOMICS}

\section{5-27 September 2020 Berlin, Germany}

Table 3: Descriptions in "Urban Master Plan 2015"

\begin{tabular}{|l|l|l|}
\hline \multicolumn{1}{|c|}{ Chapter \& Section } & \multicolumn{1}{|c|}{ Related Terms \& Frequency of Use } & \multicolumn{1}{c|}{ Analysis of Text } \\
\hline $\begin{array}{l}\text { Chapter 5: Plans by Region } \\
\text { 5-1 Konan Region }\end{array}$ & $\begin{array}{l}\text { Akatsu Elem. 3 } \\
\text { Nihon University College of Engineering 1 } \\
\text { (Shallow) Geothermal 2 }\end{array}$ & $\begin{array}{l}\text { Statement of goals for "training in } \\
\text { renewable energy" and "building of } \\
\text { regional industry } \\
\text { technology." using }\end{array}$ \\
\hline
\end{tabular}

Source: "Urban Master Plan 2015"

\subsection{Section Summary}

In the example of Koriyama, the goal is for "research and development on renewable energy" and "building industries related to renewable energy," and statements within the various plans show the level of policy standing given to the initiative. Accordingly, from this example, we can identify the significance of, and issues with, the initiative, including those from the standpoint of the municipal policy objectives of "developing renewable energy technology" and the resulting "industry building," in addition to the use of abandoned school buildings.

\section{The Process from the Start of the Initiative to the Opening of Research Facilities}

In this section, we shall summarise the process of the initiative from its beginnings through the opening of facilities, based on interviews with related entities (Table 5). Interviews were conducted in March and April 2016.

Table 4: Interviewees and Main Interview Details

\begin{tabular}{|c|c|}
\hline Interviewees & Main Interview Details \\
\hline $\begin{array}{l}\text { Renewable Energy Systems Research Center (Nihon } \\
\text { University College of Engineering) }\end{array}$ & $\begin{array}{l}\text { Conclusion of agreement and process for the initiative } \\
\text { Significance of, and issues with, an initiative from the } \\
\text { standpoint of the research centre } \\
\text { Future policies }\end{array}$ \\
\hline Koriyama City Hall Industry Creation Section & $\begin{array}{l}\text { Conclusion of agreement and process for the initiative } \\
\text { Significance of, issues with, and future potential for } \\
\text { initiative given building of related industries }\end{array}$ \\
\hline Koriyama City Hall Public Asset Management Section & $\begin{array}{l}\text { Conclusion of agreement and process for the initiative } \\
\text { Significance of, issues with, and future potential for } \\
\text { initiative given use of abandoned school buildings }\end{array}$ \\
\hline Koriyama City Hall Life Environment Section & Relationship with the city's energy policies \\
\hline $\begin{array}{l}\text { Konan Administrative Center } \\
\text { (of the two interviewed, one lives in the Akatsu area) }\end{array}$ & $\begin{array}{l}\text { Method and content of explanations to citizens } \\
\text { Methods for using abandoned school buildings in } \\
\text { Konan area } \\
\text { Significance of, and issues with, research facilities for } \\
\text { the town of Konan and Akatsu area } \\
\text { Future Expectation }\end{array}$ \\
\hline
\end{tabular}




\section{2nd International Conference on Applied Research in BUSINESS, MANAGEMENT and ECONOMICS}

\section{5-27 September 2020 Berlin, Germany}

Source: Author

\subsection{Start of the Initiative}

The research proposed by Nihon University College of Engineering was selected by NEDO in July 2014, though the university had an issue with securing research facilities. While a large area was required for equipment to conduct the research, the college could not secure enough area within the university. At the same time, the city of Koriyama was aware of the issue of managing abandoned school buildings and was searching for ways to use the buildings.

Against these circumstances, a meeting between the college and the city brought out the issue of securing research facilities. Both sides saw a match, and efforts began to use the abandoned school buildings as research facilities.

\subsection{A Decision on Area}

The Koriyama Industry and Tourism Department's Industry Creation Section and Finance Departments Public Asset Management Section were in charge of practical matters. The Public Asset Management Section presented six abandoned school buildings as candidates to the university. The candidates were then whittled down with the conditions that there be no hindrances to carrying out the research, and that the existing facilities of the elementary school could be used right away without removing them. In addition to meeting these requirements, the Akatsu Elementary School was chosen as it was on land appropriate for the use of geothermal heat, bringing down research costs ${ }^{5}$.

\subsection{Coordination with Related Organisations}

In conjunction with the decision on the area for the research centre, jurisdiction over the Akatsu Elementary School was given to the Public Asset Management Section from the school's Education Committee. The Akatsu Elementary School moved from being an "administrative property" to a "regular property", allowing broader use ${ }^{6}$.

\subsection{An Explanation to the Residents of the Akatsu Area}

The city of Koriyama and the research centre held two explanation meetings for residents of the town of Konan in October 2014 and gave an overview of experiments, facilities, and so forth. Participating in the first explanation meeting were members of the "Subcommittee to Promote Effective Utilization of the Former Elementary School"7 in the "Konan Regional Overall Promotion Council" and Konan's town chairman, with the Akatsu area mayor and town council members in the second.

\footnotetext{
5 The Public Assets Management Section conducted a boring survey with the Education Committee.

${ }^{6}$ Property which municipalities own is categorised into "administrative property" or "regular property" in general, and the former has stricter rules to deal with. In Koriyama City, in order to use administrative property, the new use must not get in the way of original purposes and it must comply with Property Rules of Koriyama City (Koriyama City Government).

${ }^{7}$ An organization made up of local residents to examine use of aban-doned school buildings.
} 


\section{2nd International Conference on Applied Research in BUSINESS, MANAGEMENT and ECONOMICS}

\section{5-27 September 2020 Berlin, Germany}

Because the Akatsu Elementary School had been used for sports events and local activities of the Akatsu area, use of the elementary school was limited, and some express the desire to provide alternative facilities. In response, the city of Koriyama prepared empty land by tearing down a meeting hall that is held in the Akatsu area (February 2015). Even with such desires, there were no explicit opinions in opposition.

\subsection{Coordination Between Koriyama and Nihon University College of Engineering}

The agreement between the city of Koriyama and Nihon University's College of Engineering was entered into November 2014. Afterwards, the city's Public Asset Management Section held discussions with the college regarding the cost burden.

The Akatsu Elementary School buildings had not been used since they were abandoned, and the facilities had experienced progressive deterioration. The city coordinated with the administrative division of the college and agreed that it would bear the minimum costs to restore the plumbing and floor prior to use, while the college would be responsible for utilities, system infrastructure used in experiments, and other costs incurred in the course of research.

\subsection{Maintenance of Research Facilities}

In changing its scope of use, the elementary school fell under various laws, which required improvements to the facilities to bring them in line with regulations. Renovations to existing buildings (March to June 2015) and the building of new facilities for experiments (stage 1 from April to September 2015), as well as required processes were done by the college and a construction company in the city. As work for the research progressed, explanation meetings and tours of the facilities here held in May and September 2015 and attended by about forty ordinary citizens.

The above process led to the opening of research facilities in September 2015.

\subsection{Thoughts and Section Summary}

The city of Koriyama and the Nihon University College of Engineering had opportunities to meet, which helped begin the initiative. The excellent relationship between the two parties certainly was a factor in identifying the awareness of the issues by both sides, and in starting the initiative.

There were many steps to the use of the abandoned school buildings, and there may be constraints in the removal of, or extending and renovating facilities. Moreover, given the demands caused by the nature of the research, the existence of the abandoned buildings was not necessarily directly connected to the use of the buildings as research facilities. 


\section{2nd International Conference on Applied Research in BUSINESS, MANAGEMENT and ECONOMICS}

\section{5-27 September 2020 Berlin, Germany}

\section{The Significance of, and Issues With, the Initiative from the Perspective of the Research Centre}

\subsection{The Significance of the Initiative}

(1) Provision of a research environment: Use of the abandoned buildings solved the problem of securing a research environment.

(2) Contribution to the municipality's energy policies: Budget approval in the Koriyama City Council in March 2016 provided "3R Promotion Project Subsidies" for technologies that use geothermal heat, including shallow geothermal heat. The subsidies are to cover part of the city of Koriyama costs for installing a system in housing that contributes to limiting $\mathrm{CO} 2$ emissions. The subsidies are for 300,000 yen, or at most $25 \%$ of the cost for installing equipment, and for five such projects. Some other cities in Fukushima Prefecture have also made decisions for subsidised projects in addition to Koriyama.

(3) Increased Community Attention on Shall Geothermal Heat Utilization Systems: The mayor refers to this research in press conferences, and also sends information on research to outside media. The city receives requests for newspaper articles on the research and tours from high schools and other municipalities both inside and outside the prefecture. Further, facilities for experiments was built in the village of Katsurao based on a May 2015 "Agreement for a Comprehensive Partnership for Reviving Katsurao" " 8 between Nihon University's College of Engineering and the village of Katsurao, located in the Futaba District of Fukushima Prefecture.

\subsection{Issues in the Initiative}

(1) Understanding of Akatsu area residents: The Nihon University College of Engineering worked with the city of Koriyama to hold multiple explanation meetings, and continues to participate in Akatsu area events. In this manner, they have acted to create good relationships and gain an understanding of locals.

(2) Application of legal restrictions: New regulations related to facilities have been applied, which have required the responses in cooperation with third parties familiar with the regulations.

\section{The Significance of, and Issues With, the Initiative from the Perspective of Koriyama}

\subsection{The Significance of This Initiative}

(1) Starting use of abandoned school buildings in need of repairs: The Public Asset Management Section raised hopes in city hall for the use of the abandoned school buildings. It is expected that use other than that of city hall is chosen by the public. However, the former

\footnotetext{
${ }^{8}$ This set forth an initiative to partner on the adoption of renewable ener-gy as an embodiment of the "Katsurao Revitalization Strategy Plan" made to summarize a plan for rebuilding and revitalization.
} 


\section{2nd International Conference on Applied Research in BUSINESS, MANAGEMENT and ECONOMICS}

\section{5-27 September 2020 Berlin, Germany}

Akatsu Elementary School was ageing, and thus use with government involvement was not possible ${ }^{9}$.

For this initiative, use of the Akatsu Elementary School was based on the agreement, which enabled repair work on the facilities to move forward. In other words, the abandoned school buildings were chosen through a process of elimination according to the requests of the university, and the ageing that had prevented the use of the buildings was one factor that lowered its importance.

(2) Reflection of research results in related energy projects of Koriyama: Geothermal heat, broadly speaking and including shallow geothermal heat, is currently at the stage of auxiliary use. As technologies for the use of shallow geothermal heat are developed, and adoption becomes anticipated, it is possible that auxiliary projects will be created focusing on shallow geothermal heat.

(3) Potential to contribute to the region through creation and building of industry: The Nihon University Renewable Energy Systems Research Centre is currently the nucleus of technology development, with potential for the technologies to make their way into many businesses and contribute to the development of related industries across regions, including the city of Koriyama. Multiple businesses are participating in the research, making the scope across which the technologies can be adopted very broadly.

\subsection{Issues with the Initiative}

(1) Selection of abandoned buildings for use: While situations of the abandoned school buildings vary, use of an abandoned school building depends on whether they are appropriate for particular research.

(2) Agreement on sharing of costs: Many abandoned school buildings are ageing, and the sharing of costs for building out facilities can be a point of contention.

\subsection{Discussion and Section Summary}

There is tremendous significance to the use of the abandoned school buildings without the involvement of the city of Koriyama in that use. Ageing is often the reason why abandoned school buildings are not used, but it will become less critical if municipalities decide to allow external organisations to use the schools in advance under the assumption that someone will use them. However, the schools must also meet the conditions set by the university or research centre, making it challenging to avoid costs for further renovations to facilities. But, having an external organisation use the abandoned schools does make it easier to keep the government burden lower.

Regarding the adoption of renewable energy, a project began in advance of the adoption of technologies for using shallow geothermal heat, and this project may come to fruition in the future. Likewise, regarding the building of industry, growth in related industries is expected due to the expansion of technologies. In other words, the city of Koriyama is moving ahead with

\footnotetext{
${ }^{9}$ However, the university did not feel that the Akatsu Elementary School was especially decrepit when compared with other abandoned school buildings.
} 


\section{2nd International Conference on Applied Research in BUSINESS, MANAGEMENT and ECONOMICS}

\section{5-27 September 2020 Berlin, Germany}

energy and industrial policies, and not just the use of abandoned school buildings, by supporting the loaning of the buildings. The role played in promoting this initiative by projects and institutions is considerable. At the same time, reducing time spent on discussion points with the university over the current state of the abandoned school buildings and meeting research conditions, or sharing the cost burden, are issues.

\section{The Significance of, and Issues With, the Initiative from the Perspective of Akatsu Area Residents}

\subsection{The Significance}

There is significance in the economic ripple effect of the revitalisation of the Akatsu area. The awareness of residents is steadily increasing through the aforementioned local explanation meetings and efforts at local interaction. There may be other initiatives in the area to allow the Akatsu Elementary School to be in continual use, including for purposes other than as a university research centre. Moving forward with the cooperation of many entities, including organisations like the "Subcommittee to Promote Effective Utilization of the Former Elementary School" in the "Konan Regional Overall Promotion Council".

\subsection{Issues}

The Akatsu Elementary School would return to being an abandoned school if the use of the research facilities were to come to an end. Avoiding this fate depends on whether the school will be used long-term. It is also important for the municipality to move aggressively for the school to be used if there are no proposals or requests for use within the region.

\section{Conclusion}

\subsection{Conclusion of This Paper}

\section{(1) Process}

The good relationship between the city of Koriyama and the Nihon University College of Engineering likely aided in the use of the Akatsu Elementary School, though there were many steps in that process. Moreover, because there are many conditions such as research constraints and the condition of the abandoned buildings, it is possibly challenging to find abandoned school buildings that would be appropriate for use as research facilities.

(2) Significance of, and Issues with, Related Entities

Along with securing research facilities for the university and the research centre, there is significance in finding a means to bring the results of research to society. Moreover, there is significance in the city of Koriyama, finding a way to use the abandoned school. This suggests that partnering with an external organisation such as a university may be an effective way to put abandoned schools to use.

While it is significant that the initiative may result in regional revitalisation, one issue is whether the use of the abandoned school will continue in the long-term. 


\section{2nd International Conference on Applied Research in BUSINESS, MANAGEMENT and ECONOMICS}

\section{5-27 September 2020 Berlin, Germany}

\section{(3) Contributions to Municipality Policies}

The initiative demonstrates that use of the abandoned school buildings can function as a means to push the policies of renewable energy adoption and industry building.

As to energy policies, renewable energy adoption may increase by turning the technologies found through research into auxiliary businesses. As to industrial building, it is expected that technologies will be adopted by a more significant number of businesses, leading to growth in related industries.

\subsection{Policy Suggestions}

It is essential that, by building good relations, the local government and university were able to cooperate to solve each other's problems and create a firm foundation. Also, it was practical for the municipality to leverage an external entity and initiative discussions for the use of abandoned school buildings.

It is also effective for the municipality to ascertain regulations such as guidelines for sharing costs and procedures for simplifying required processes, as well as to ascertain the current state of each abandoned school building and present it to the external entity in order to meet the individual needs of the university. Also, the municipality is expected to create a framework for subsidies, and to take on a support role to put research results back into the community to increase community awareness. As the municipality becomes involved and uses public facilities, both the university and the municipality must ensure the research is significant to the community, and that research results can be put to general uses.

\section{References}

[1] Cabinet Secretariat Urban Rebuilding Headquarters (2005/2007) "Questionnaire Survey on the State of Initiatives Between Universities and Regions"

[2] Koriyama City Living Environment Section (2015) "An Energy Vision for Koriyama"

[3] Koriyama City Urban Planning Section (2015) "Koriyama Urban Master Plan 2015"

[4] Ministry of Land, Infrastructure, Transport and Tourism;

https://www.mlit.go.jp/crd/city/plan/03_mati/02/index.htm (Accessed on August 13, 2020)

[5] Koriyama City Government;

https://www.city.koriyama.lg.jp/sangyo_business/facilitymanagement/19559.html (Accessed on August 13, 2020) 